\title{
Y CHROMOSOME AND MALE INFERTILITY
}

\author{
Csilla Krausz $^{1,2}$ and Ken McElreavey ${ }^{2}$ \\ ${ }^{I}$ Andrology Unit, Department of Clinical Physiopathology, University of Florence, Florence, Italy. Immunogenetique Humaine, \\ Institut Pasteur, Paris , France
}

\section{TABLE OF CONTENTS}

\author{
1. Abstract \\ 2. Introduction \\ 3. Y chromosome \\ 4. Yq deletions and oligo/azoospermia \\ 5. Genes and genes families of the $A Z F a, A Z F b$ and $A Z F c$ regions \\ 6. Clinical aspects of $Y q$ deletions \\ 6.1. Incidence of microdeletions \\ 6.2. Correlations between genotype and phenotype \\ 6.3. The origin of $Y$ deletions \\ 6.4. The mechanism of $Y$ deletions \\ 6.5. Fertility and $Y$ microdeletions \\ 6.6. Assisted reproductive techniques and $Y$ deletions
}

7. Future directions

\section{ABSTRACT}

Male factor infertility accounts for about half the cases of couple infertility. In more than $60 \%$ of cases the origin of reduced testicular function is unknown but they may have an unidentified genetic anomaly. Microdeletions of the long arm of the human Y chromosome are associated with spermatogenic failure and have been used to define three regions of $\mathrm{Yq}(\mathrm{AZFa}, \mathrm{AZFb}$ and $\mathrm{AZFc})$ that are recurrently deleted in infertile males. Several genes have been identified within this region and have been proposed as candidates for infertility. Many of these genes encode proteins involved in post-transcriptional gene expression and therefore could participate in the sperm maturation process.

About $10-15 \%$ of azoospermic and about $5-10 \%$ of severely oligozoospermic men have Yq microdeletions. The deletions are associated with a wide range of histological pictures ranging from Sertoli Cell Only Syndrome (SCOS) to spermatogenic arrest and severe hypospermatogenesis. Assisted reproduction techniques such as in vitro fertilization (IVF) and Intra Cytoplasmic Sperm Injection (ICSI) alone, or in association with testicular sperm retrieval, represent an efficient therapy for these patients. However the potential of these techniques to transmit genetic defects causing male infertility raises the need for a systematic genetic screening and genetic counselling of these patients.

\section{INTRODUCTION}

Infertility affects about $15 \%$ of couples, and in $40-50 \%$ of cases the male partner has quantitative or qualitative abnormalities of sperm production (1). Spermatogenesis is a complex biological process which depends on a precisely controlled cascade of developmental genes orchestrating spermatogonial cell proliferation, chromosomal reduction divisions to produce a haploid genome in each daughter cell and, finally, morphological differentiation of these latter cells into mature sperm. Mutations in any of the genes in this pathway can have a profound impact on the testis as a whole. Evidence that genetic disorders may disrupt the process of spermatogenesis are multiple: i) interference of certain chromosome aneuploidies with meiotic cell divisions causes sterility by asynaptic chromosome pairing events and distortion of sex vescicle formation (2) ii) the role of autosomal genes in spermatogenesis is highlighted by several published familial cases of male infertility and from mouse gene "knock-out" studies $(3,4,5,6)$ iii) association of male infertility and $\mathrm{Y}$ chromosome deletions indicate the presence of genes necessary for male germ cell development on the $\mathrm{Y}$ chromosome(7-27). The role of $\mathrm{Y}$ chromosome factors in spermatogenesis represents one of the most rapidly developing field in andrology. Regions of the Y chromosome that are recurrently deleted in men with spermatogenesis failure are currently being defined and, in parallel, many novel $\mathrm{Y}$ chromosome genes are being identified within these deletion intervals.

A critical analysis of the available data on the Y chromosome and male infertility are the subject of the present review.

\section{Y CHROMOSOME}

The Y chromosome comprises only $2-3 \%$ of the haploid genome. It is an acrocentric chromosome and consequently contains a short arm (Yp) and a long arm (Yq), demarcated by a centromeric region essential for chromosome 


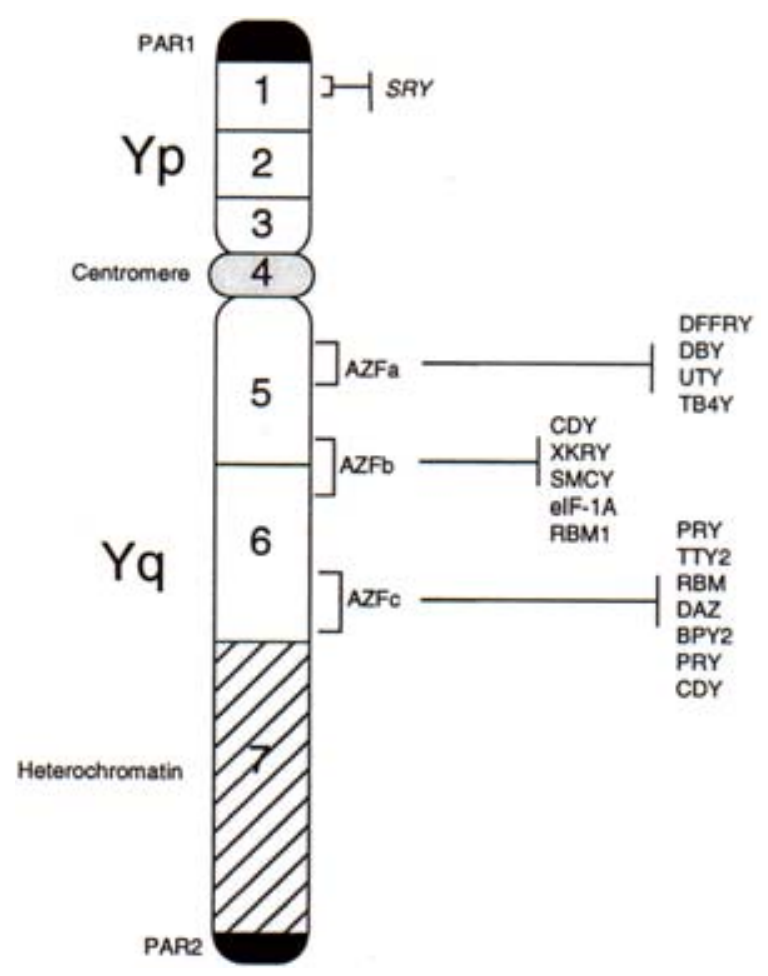

Figure 1. Schematic representation of the Y chromosome showing the seven deletion intervals. Pseudoautosomal region 1 and 2 are indicated (PAR1, PAR2).The regions $\mathrm{AZFa}, \mathrm{AZFb}$ and $\mathrm{AZFc}$ and genes located within them are illustrated.

chromosome segregation (figure 1). Cytogenetic studies have defined three regions:

1) Pseudoautosomal regions (PAR) which are located at the end of the short arm (PAR1) and at the end of the long arm (PAR2) of the chromosome.

2) The euchromatic region which is distal to the PAR1 consists of the short arm paracentromeric region, the centromere and the long arm paracentric region.

3) The heterochromatic region comprises distal Yq. This region is polymorphic in different male populations (variation in length), constituting almost half the chromosome in some men while being undetectable in others. The pseudoautosomal region is where the $\mathrm{Y}$ chromosome pairs and exchanges genetic material with the pseudoautosomal region of the $\mathrm{X}$ chromosome during male meiosis. Consequently genes located within the pseudoautosomal region are inherited in the same manner as autosomal genes. The majority of the length of the $\mathrm{Y}$ $(95 \%)$ is termed "NonRecombining Y" (NRY). This region represents the only haploid compartment of the human genome and includes the heterochromatic and euchromatic regions of the chromosome. The heterochromatic region is assumed to be genetically inert and it is mainly composed mainly of two highly repetitive sequences families, DYZ1 and DYZ2, containing about 5000 and 2000 copies of each respectively. The euchromatic region has numerous highly repeated sequences but also contains genes involved in sex determination, gonadoblastoma, stature control, Turner stigmata and spermatogenesis (28).

\section{Yq DELETIONS AND OLIGO/AZOOSPERMIA}

The first association between spermatogenic failure and an underlying genetic cause was demonstrated by Tiepolo and Zuffardi in 1976 (29) in a report of six azoospermic patients carrying microscopically detectable deletions of the distal portion of Yq. In four cases the deletion was de novo (their fathers were tested and found to carry intact $\mathrm{Y}$ chromosome). On the basis of this finding they proposed the existence of a spermatogenesis factor, the "azoospermia factor" (AZF) encoded by a gene on distal Yq. However, it was not until the mid 1980's when Y chromosome specific probes were developed, that the region(s) associated with spermatogenic failure were defined (30). The order of a series of anonymous probes along the length of the $\mathrm{Y}$ chromosome in 27 individuals (XX males, XX hermaphrodites and infertile men with microscopically detectable deletions of $\mathrm{Y}$ ) led to the construction of a map consisting of seven deletion intervals (Fig. 1; 30). Vollrath and colleagues (31) enhanced the resolution of this map by developing more than 200 sequence-tagged sites (STS: short tracts of DNA that act as a landmark to define position on a physical map) along the length of the Y chromosome and ordered the STS markers using a large panel of individuals with $\mathrm{Y}$ chromosome deletions. These markers have permitted simple deletion analysis in infertile males by the Polymerase Chain Reaction (PCR). Many STS based screening programmes have been undertaken in patients affected by azoo/severe oligozoospermia in order to define the AZF locus and isolate candidate genes for AZF. In the most extensive studies to date, Vogt et al (11) examined 370 azoospermic and severe oligozoospermic patients for the presence of 76 Yq11 loci. This analysis defined 3 non-overlapping regions of Yq, termed AZFa, AZFb and AZFc that are deleted in men with azoospermia or severe oligozoospermia.

\section{GENES AND GENE FAMILIES OF THE AZFa, AZFb AND AZFc REGIONS.}

The AZFa region is located in proximal $\mathrm{Yq}$ within deletion interval 5 and it is estimated to be between 1 and $3 \mathrm{Mb}$ in size (Fig.1). Several genes have been identified in this region, either by direct cloning of the human gene or by the cloning of the mouse gene followed by identification of the human homolog. These genes include: the homolog of the Drosophila Developmental gene Fats Facets (DFFRY), Dead Box Y (DBY), Ubiquitous TPR motif $Y$ (UTY) and a Tymosin B4Y isoform (TB4Y). The DFFRY gene encodes a protein that may be involved in deubiquitination, a process which regulates protein degradation by preserving proteins marked by conjugation with ubiquitin for digestion by the proteasome. DFFRY has been proposed to play a role in gametogenesis, based on the phenotype associated with mutation in the drosophila homolog of the gene (32). DBY, UTY and TB4Y all appear to be involved in cellular "housekeeping" and share several characteristics: (i) ubiquitous tissue expression; (ii) monocopy on the $\mathrm{Y}$ chromosome; (iii) each has an $\mathrm{X}$ homologue with $>85 \%$ amino acid sequence identity that escapes $\mathrm{X}$ inactivation. DBY is predicted to encode an RNA helicase (33). UTY 
has a mouse $\mathrm{Y}$ homologue recently shown to encode an $\mathrm{H}-$ $\mathrm{Y}$ antigen (34). TB4Y encodes a $\mathrm{Y}$ isoform of tymosin B4, which may be involved in the sequestration of actin (35).

The AZFb region extends between deletion interval 5 and proximal portion of deletion interval 6. Its size is estimated between 1-3 Mb. To date five genes have been described within this interval: RNA-Binding Motif (RBM, formerly termed YRRM), Chromodomain Y (CDY), XK Related Y (XKRY), eukaryotic translation initiation factor 1A (eIF-1A) and Selected Mouse cDNA on the Y (SMCY). RBM, CDY and XKRY have multiple copies on the long arm of the $\mathrm{Y}$ chromosome. More than 30 RBM genes and pseudogenes are spreaded over both arms of Y chromosome $(36,37,38)$. They encode germ cell specific nuclear proteins containing an RNA-binding motif and four copies of a SRGY repeat. The $\mathrm{AZFb}$ region contains at least one functional RBM copy, located in the distal portion of this deletion interval. Deletions of distal $\mathrm{AZFb}$ (region sY142-sY145) have been shown to correlate with absence of protein recognition by an antibody directed against RBM in testicular sections (39). The RBM gene family appears to be specifically expressed in nuclei of spermatogonia and early spermatocytes (40).

Both CDY and XKRY are expressed specifically in adult testis. CDY encodes a novel protein with a chromodomain which may interact with the heterochromatin and thus modify DNA or chromosomal proteins (41). XKRY encodes a protein with similarity to $\mathrm{XK}$, a putative membrane transport protein (42). Both SMCY and eIF-1AY appear to be present as single copy genes. The biological function of SMCY is unknown but it encodes a male specific histocompatibility antigen (H-Y). eIF-1A has been mapped to 5Q and subsequently defined between sY127-sY129 (43). This gene encodes a Y isoform of a eIF-1A, an essential translation initiation factor (44). The X-Y amino acid sequence identity is $97 \%$, and the $\mathrm{X}$ homologue escapes inactivation. Both $\mathrm{X}$ and $\mathrm{Y}$ homologues are ubiquitiously expressed, with a high level of expression in the testis.

The AZFc region, formerly termed the AZF minimal region, is located in close proximal to the heterochromatin. Its size is approximately $1.4 \mathrm{Mb}$ and it contains the DAZ (Deleted in Azoospermia) gene cluster $(7,45)$, two copies of PTP-BL Related Y (PRY), Basic Protein Y2 (BPY2), Testis Transcript Y2 (TTY2), as well as copies of CDY, RBM. Like RBM, DAZ encodes a testisspecific protein that has a single RBM domain and a series of seven tandem repeats of a 24 aa unit termed the DAZ repeat. The biological function of the DAZ motif is unknown. Although DAZ was originally considered to be a single copy gene (7), there are at least six to nine copies of DAZ, all located within the AZFc region, each of whom appears to differ substantially in the sequence and organisation of the DAZ repeats $(45,46)$. DAZ is transcribed in adult human germ cells, and its fruit fly homologue, boule, is essential in the meiotic stages of Drosophila spermatogenesis (47). DAZ is homologous to an autosomal gene with a single DAZ repeat named DAZL1 (DAZ like-autosomal 1). DAZL1 is located on human chromosome 3 (45) and it has been hypothesised that Y located DAZ originated from the translocation and amplification of this ancestral autosomal gene (45). DAZL1 is expressed specifically in the testis and mutations of the gene may be a cause of autosomal recessive male infertility. Mice do not have a Y-located DAZ gene but have a single autosomal Dazl1 gene (48). Targeted disruption of Dazll leads to a complete absence of gamete production in both testis and ovary, demonstrating that dazl1 is essential for development and survival of germ cells (49).

Although the absence of the DAZ gene family has been proposed as the cause of the AZFc phenotype, deletions within the AZFc region that apparently do not include the DAZ gene family $(9,12,15)$ have been reported recently. Moreover, Vereb et al 1997 (16) sequenced the five terminal DAZ exons (which contain the potential RNA binding domain) in 30 non-obstructed azoospermic males, and they failed to find mutations. This suggests that either $\mathrm{DAZ}$ is not AZF, or that large deletions are the primary cause of the inactivation of the locus, perhaps including other functionally important genes. There is a lack of evolutionary constrains in the $\mathrm{Y}$ chromosome DAZ gene family in primates including man, suggesting that it plays a limited role in male spermatogenesis (50).

Other genes have been identified within AZFc (28). PRY codes for a novel protein with similarity to PTP-BL, a putative protein tyrosin phosphatase (51). BPY2 encodes a novel basic protein of unknown function, whilst no significant open reading frame has been identified in the TTY2 transcript. They are all expressed specifically in the testis and have multiple copies on the Y (28).

For the moment it is not known whether the Y chromosome harbours a specific set of spermatogenesis genes which act as master regulators of this process or as minor factors which enhance the quality or efficiency of spermatogenesis. The positions of genes within the three AZF regions, their expression pattern and the data on their homologs (DFFRY, DAZ) are suggestive but only circumstantial evidence for their involvement in the control of spermatogenesis. The finding of small intragenic deletions, rearrangements or point mutations would provide direct proof for the role of these genes in spermatogenic failure.

\section{CLINICAL ASPECTS OF Yq DELETIONS}

Since 1994 several combined clinical and molecular studies have been performed in order to (i) define recurrently deleted regions of Yq, (ii) determine the incidence of microdeletions among azoo-and oligozoospermic men; (iii) correlate the size and position of the deletions with the infertile phenotype. The need for such knowledge has been sharply focused recently with the introduction of sophisticated assisted reproductive technologies such as intracytoplasmic sperm injection (ICSI) which allows pregnancy in the partners of patients affected by severe hypospermatogenesis or Sertoli Cell Only Syndrome (SCOS) type II. Since Y microdeletions may be associated with these conditions, Y-bearing sperm 
Table 1. Summary of Y-chromosome microdeletions reported from 1995-98.

\begin{tabular}{|c|c|c|c|c|c|c|c|c|c|}
\hline \multirow{2}{*}{$\begin{array}{l}\text { Source } \\
\mathbf{A}\end{array}$} & \multirow[t]{2}{*}{ Type } & \multicolumn{2}{|c|}{$\mathrm{n}^{\circ}$ deleted $/ \mathrm{n}^{\circ}$ total pat. $(\%)$} & \multicolumn{2}{|c|}{$\begin{array}{l}\mathrm{n}^{\circ} \text { deleted } / \mathbf{n}^{\circ} \\
\operatorname{azoo}(\%)\end{array}$} & \multicolumn{2}{|l|}{$\begin{array}{l}\mathrm{n}^{\circ} \text { deleted } / \mathbf{n}^{\circ} \\
\text { oligo }(\%)\end{array}$} & \multirow[t]{2}{*}{$\mathbf{n}^{\circ}$ deleted $/ \mathbf{n}^{\circ}$ fertile } & \multirow[t]{2}{*}{$\mathrm{n}^{\circ} \mathrm{STS}$} \\
\hline & & & & & & & & & \\
\hline Reijo et al. 1995 & $\mathrm{D}$ & $12 / 89$ & (13) & $12 / 89$ & (13) & $\mathrm{nt}$ & & $0 / 90$ & 84 \\
\hline Quereshi et al. 1996 & $\mathrm{~A}$ & $8 / 100$ & (8) & $4 / 51$ & $(7,8)$ & $4 / 47$ & $(8,5)$ & $0 / 80$ & 23 \\
\hline Stuppia et al. 1996 & A & $6 / 33$ & (18) & $4 / 19$ & (21) & $2 / 14$ & (14) & $0 / 10$ & 14 \\
\hline Reijo et al. 1996 & $\mathrm{D}$ & $2 / 35$ & $(5,7)$ & $\mathrm{nt}$ & & $2 / 35$ & $(5,7)$ & nt & 118 \\
\hline Vogt et al. 1996 & A & $12 / 370$ & $(3,2)$ & $?$ & & ? & & $0 / 200$ & 76 \\
\hline Najbamadi et al.1996 & $\mathrm{A}^{*}$ & $11 / 60$ & (18) & $10 / 50$ & $(20)$ & $1 / 10$ & $(10)$ & $0 / 16$ & 26 \\
\hline Nakahori et al. 1996 & $\mathrm{C}$ & $20 / 153$ & (13) & $18 / 135$ & (13) & $2 / 18$ & (11) & nt & 23 \\
\hline Foresta et al. 1997 & A & $11 / 38$ & (28) & $6 / 16$ & (37) & $5 / 22$ & (22) & $0 / 10$ & 15 \\
\hline Vereb et al. 1997 & $\mathrm{D}$ & $5 / 168$ & $(2,9)$ & $5 / 43$ & (11) & $0 / 115^{\circ}$ & (0) & $0 / 55$ & ? \\
\hline Mulhall et al. 1997 & $\mathrm{D}$ & $8 / 83$ & $(9,6)$ & $8 / 83$ & $(9,6)$ & nt & & $0 / 0$ & $?$ \\
\hline Simoni et al. 1997 & B & $5 / 168$ & $(2,9)$ & $3 / 74$ & (4) & $2 / 94$ & $(2,1)$ & $0 / 86$ & 4 \\
\hline Van der Vent et al. 1997 & $\mathrm{~A}$ & $2 / 152^{*}$ & $(1,3)$ & $0 / 10$ & (0) & $1 / 137^{\circ}$ & $(0,7)$ & $0 / 50$ & 30 \\
\hline Girardi et al. 1997 & $\mathrm{C}$ & $8 / 156^{*}$ & $(5,1)$ & $6 / 105$ & $(5,7)$ & $2 / 41$ & $(4,8)$ & $0 / 6$ & 36 \\
\hline Selva et al. 1997 & $\mathrm{C}$ & $2 / 81$ & $(2,4)$ & $0 / 11$ & (0) & $2 / 60$ & $(3,3)$ & nt & 5 \\
\hline Stuppia et al. 1998 & B & $14 / 109^{*}$ & (13) & $6 / 42$ & (14) & $10 / 67$ & (15) & $0 / 13$ & 27 \\
\hline Foresta et al. 1998 & A & $10 / 18$ & $(55,5)$ & $10 / 18$ & $(55,5)$ & nt & & $0 / 10$ & 29 \\
\hline Grimaldi et al. in press & $\mathrm{B}$ & $5 / 67$ & $(7,4)$ & $4 / 60$ & $(6,6)$ & $1 / 7$ & (14) & $\mathrm{nt}$ & 18 \\
\hline $\begin{array}{l}\text { B } \\
\text { Kent-First et al. } 1996\end{array}$ & & $1 / 32$ & $(3.1)$ & $0 / 30$ & $(0)$ & $1 / 19$ & $(5.2)$ & $0 / 200$ & 5 \\
\hline Pryor et al. 1997 & & $14 / 200$ & (7) & $6 / 26$ & (23) & $7 / 72$ & $(9.7)$ & $4 / 200$ & 85 \\
\hline Kremer et al. 1997 & & $7 / 164$ & $(4.2)$ & $0 / 19$ & (0) & $7 / 111$ & (6.3) & $0 / 100$ & 8 \\
\hline Barbeaux et al. in press & & $22 / 131$ & (16) & $11 / 83$ & (13) & $11 / 46$ & (24) & $0 / 40$ & 21 \\
\hline Krausz et al. submitted & & $3 / 134 *$ & $(2.2)$ & $1 / 22$ & (4.5) & $2 / 95$ & (2.1) & $0 / 10$ & 10 \\
\hline
\end{tabular}

A: Studies on "selected patients". Note that selection criteria varies between studies. Type A: excluded all known causes of azoospermia (not always clear criteria for oligozoospermia). Type $A^{*}$ : excluded all known causes of azoospermia and oligozoospermia (karyotype not performed) Type B studies: excluded all known causes of azoo-and oligozoospermia with the exception of varicocele and cryptorchidism; Type C: excluded only obstructive azoospermia and cytogenetic anomalies; Type D: excluded only obstructive azoospermia (karyotype not performed in all cases); * patients with abnormal karyotype have been removed. ${ }^{\circ}$ over $50 \%$ of oligospermic patients have $>5 \times 10^{6} / \mathrm{ml}$ of spermatozoa. B: Studies on « unselected patients ». * in over $70 \%$ of patients abnormal andrological finding have been found.

carrying the deletion will transmit this genetic defect to male offspring.

\subsection{Incidence of microdeletions}

The incidence of microdeletions in infertile men varies between studies, from $1 \%$ Van der Ven (20) to $55 \%$ Foresta (25) (see table 1). Factors related to study design are probably the most important elements influencing this parameter. For example, study populations are often variable ranging from (i) azoospermic patients, (ii) azoospermic and oligozoospermic patients, (iii) azoo/oligozoospermic and infertile normospermic patients. Both oligozoospermia and azoospermia are symptoms and represent a heterogeneous group of different aetiologies. The majority of clinical studies include "selected" patients affected by idiopathic azoo-or oligozoospermia while others include "unselected" infertile men with known or unknown cause of infertility. Unfortunately, there is no agreement between studies concerning what constitutes idiopathic infertility. Patients with abnormal andrological findings, such as varicocele and history of cryptorchidism are considered as idiopathic in some studies and as nonidiopathic in others. In addition, it is not clearly indicated if a complete medical history and a through medical and laboratory examination were performed. In some cases the karyotype is absent. There are also important differences in the number of patients examined; in general studies with low patient numbers report a higher frequency of deletions. Another variable which may also affect the estimation of frequency of Yq deletions is marker density or the position of markers. However, recently it has been noted that there is not a statistically significant correlation between the frequency of microdeletions and the number of STSs markers used (52).

Finally, differences in deletion frequency and/or localisation between studies may reflect genuine population variances, perhaps related to a combination of particular Y chromosome haplotypes, genetic background or environmental influences.

\subsection{Correlation between genotype and phenotype}

Vogt and colleagues (11) proposed that $\mathrm{Y}$ chromosome microdeletions follow a certain deletion pattern with three commonly deleted non-overlapping subregions in proximal, middle and distal Yq11, designated as $\mathrm{AZFa}, \mathrm{b}$ and $\mathrm{c}$ respectively. In each subregion, it has been suggested that the deletion is associated with distinct histopathological profile. Deletions occurring in AZFa result in type I Sertoli Cell Only Syndrome (SCOS) (no spermatogonia present), deletions in $\mathrm{AZFb}$ result in spermatogenic arrest (SGA) usually at spermatocyte stage, and deletions in AZFc are associated to type II SCOS (some spermatogonia is present with limited spermatogenesis) or to hypospermatogenesis. However, it is not yet clear if a strict genotype/phenotype correlation exists. For example Quereshi et al. reported a deletion of AZFa associated with severe oligozoospermia (8) and Pryor et al. (14) described an oligospermic infertile man with a deletion of AZFb. The absence of 
genotype/phenotype correlations may be due to a number of factors. The most important is the absence of a common protocol to carry out testicular biopsies (number of sample taken) and to categorise the histopathology. Multiple testicular biopsies can reveal the presence of islands where normal spermatogenesis occurs and thereby change the diagnosis of SCOS type I or pure SGA to SCOS type II. It is also important to remember that the histological pattern may vary with the duration of the pathological lesion i.e. a progressive reduction of germ cells may occur with time ultimately leading to the appearance of SCOS type I. Evidence for this phenomenon is provided by some clinical findings: Girardi et al. (21) followed a patient with an AZFc deletion over 30 months and they found a progressive decrease in sperm concentration from severe oligozoospermia to azoospermia. Moreover, previous paternity and/or oligozoospermia has been reported in azoospermic patients with AZFc deletions (19).

Despite some apparently conflicting findings reported in the literature some general genotype/phenotype tendencies are observed: (i) microdeletions have been found almost exclusively in males affected by azoospermia or severe oligozoospermia (ii) microdeletions have also been found in patients with abnormal andrological findings (iii) a higher frequency of $\mathrm{Yq}$ deletions are found in azoospermic vs oligozoospermic patients and in well defined idiopathic infertility vs infertility with known aetiology; (iv) large deletions are, in general, associated with a more severe spermatogenic defect; (v) AZFa deletions are less common (1-5\%) and are generally, associated with SCOS type I; (vi) AZFc and AZFc + b deletions are the most frequent deletions, and they may be associated with a variety of spermatogenic failure including oligozoospermia.

\subsection{The origin of $Y$ deletions}

Apart from a few inherited cases (see below), the majority of deletions occur as de novo events. The cellular origin where $\mathrm{Y}$ chromosome deletions occur is not clear. A testicular origin of deletions seems the most likely (a meiotic or spermatid origin) although deletions could arise in fertilised eggs or embryos, to prevent the formation of spermatogonia in the fetus and subsequently impair spermatogenesis in the adult (53). Mosaicism in the germ cell lineage may explain the finding of $\mathrm{Y}$ deletions in two male children conceived through ICSI even though the deletion was not detected in their infertile father's lymphocytes. (54).

\subsection{The mechanism of $Y$ deletions}

The relatively high frequency of $\mathrm{Y}$ deletions suggests that the $\mathrm{Y}$ chromosome is susceptible to the spontaneous loss of genetic material. The nature of the mechanism remain speculative. One possibility is aberrant recombination events between areas of homologous or similar sequence repeats (55), (for example Alu repeats or gene families) between the $\mathrm{X}$ and $\mathrm{Y}$ chromosomes or within the $\mathrm{Y}$ chromosome itself by unbalanced sister chromatid exchange (56). The instability of the Y chromosome may be related to the high frequency of repetitive elements clustered along the length of the $\mathrm{Y}$ chromosome. However, the question remains as to why some men have AZF deletions and others do not. There may be particular $\mathrm{Y}$ chromosome sequence organisations that facilitates deletion formation of the AZF regions. Consequently some individuals may be more susceptible to deletion formation than others. A Y chromosome haplotype that is susceptible to aberrant $\mathrm{X} / \mathrm{Y}$ exchange during male meiosis, leading to $\mathrm{Y}$-positive 46,XX maleness has recently been described (57). The analysis of Y chromosome haplotypes in men with $\mathrm{Y}$ deletions compared to appropriate fertile male controls should resolve this question.

\subsection{Fertility and $Y$ microdeletions}

A total of 1176 fertile men have been included in Y microdeletion screening studies as controls. In one study, microdeletions were found in 4 fertile men. All 4 fertile men with Y deletions (14) had small microdeletions of distal AZFb. These may be rare polymorphic variants, or the "fertile" men may themselves have been oligozoospermic. In most studies, fertile men have been defined on the basis that they have fathered at least one child, whilst their sperm parameters were not described. This information is necessary since male fertility can coexist with reduced sperm production. A total of 91 near male relatives (father or brother) of patients with deletions have been screened. Five cases have been reported where fathers have transmitted AZFc deletions to their sons.In one of them, the size of the deletion was larger in the infertile son (58), whilst in the other 4 the size of the deletion between fathers and sons was apparently the same. One of the four father had low sperm concentrations and was able to father only one child (14). This finding suggests that male hypofertility can be compensated by normal female fertility status and that sperm production may vary with time in patients with deletions. There is no data available on the semen qualities of the other fathers.

\subsection{Assisted reproductive techniques and $Y$ deletions}

$\mathrm{Y}$ chromosome screening is recommended to all patients seeking ICSI or IVF and presenting a sperm concentration $<5 \times 10^{6} / \mathrm{ml}$. The diagnosis of Y microdeletions gives the cause of the spermatogenic failure and is useful for clinicians as it avoids unnecessary medical (hormonal and non hormonal) and surgical (varicocele operations) treatments. For the moment, the only effective therapy for these patients is ICSI (in oligozoospermic patients) or ICSI combined with testicular sperm retrival (in azoospermic patients). Recently it has been reported that the type of Y chromosome microdeletion in azoospermic patients could have some prognostic value in terms of the probability to find some mature sperm in testicular tissue following Testicular Sperm Extracton (TESE). The preliminary results indicate that $\mathrm{AZFb}$ deletions are associated with no sperm retrival, while in about $71 \%$ of patients with AZFc deletions mature spermatozoa has been found $(59,60)$.

Spermatozoa from patients with Y microdeletions have been found to be fully fertile both following ICSI and IVF procedures $(18,61)$. The rate of fertilization of eggs and embryo development are comparable to that of men with apparently no Y deletion. Although a father will give 
to his son this genetic defect, the phenotype of son may vary substantially and the extent of subfertility or infertility cannot be entirely predicted. Screening of ICSI male babies for $\mathrm{Y}$ deletions is necessary, and a careful long term follow up of ICSI sons is important in order to understand more about the safety of these techniques. Since certain Y deletions are associated with a progressive change from oligozoospermia to azoospermia $(19,21)$, preventive therapy (cryoconservation of sperm for successive assisted reproductive techniques) could be proposed to affected sons.

\section{FUTURE DIRECTIONS}

Although substantial efforts have been made in this field, there are many questions that remain unanswered. Genotype/phenotype correlations may become clearer, with more accurate patient selection criteria, an improved clinical and histopathological investigation and a precise definition of the different phenotypes. Studies of groups of men of different ethnic/geographic origins are needed to determine if there are population differences between the frequency, position or extent of the deletions. Studies on normospermic men rather than "fertile" males will provide evidence about the type of polymorphic deletions with no clinical relevance.

Currently, most research activities are concentrated on deletion characterisation and gene discovery. Little is known about the biological functions of the proteins encoded by $\mathrm{Y}$ chromosome genes. It is interesting to note that a significant proportion of these may be involved in RNA metabolism (DAZ, RBM, eIF-1A, DBY). RNA processing is an important aspect of germ cell differentiation (62). As more is known about the biological roles of these factors, it may be possible in the future to develop more appropriate and knowledge based therapies.

\section{REFERENCES}

1. Mosher WD (1985) Reproductive impairements in the United States, 1965-1982. Demography. 22, 415-430.

2. Chaganti RS, Jhanwar SC, Ehrenbard LT, Kourides IA, Williams JJ. (1980) Genetically determined asynapsis, spermatogenic degeneration and infertility in men. Am. J. Hum. Genet. 32, 833-848.

3. Cantu JM, Rivas F, Hernandez-Jauregui P, Diaz M, Cortes-Gallegos V, Vaca G, Velazquez A, Ibarra B. (1981) Meiotic arrest at first spermatocyte level: a new inherited infertility disorder. Hum. Genet. 59, 380-385

4. Lilford R, Jones AM, Bishop DT, Thornton J, Mueller R. (1994) Case-control study of wheter subfertility in men is familial. B.M.J. 309, 570-573.

5. Kastner P, Mark M, Leid M, Gansmuller A, Chin W, Grondona JM, Decimo D, Krezel W, Dierich A, Chambon P. (1996) Abnormal spermatogenesis in RXR beta mutant mice. Genes \& Dev. 10, 80-92

6. Baker SM, Plug AW, Prolla TA, Bronner CE, Harris AC, Yao X, Christie DM, Monell C, Arnheim N, Bradley A,
Ashley T, Liskay RM. (1996). Involvement of mouse Mlh1 in DNA mismatch repair and meiotic crossing over. Nature Genet. 13, 336-342.

7. Reijo R, Lee TY, Salo P, Alagappan R, Brown LG, Rosenberg M, Rozen S, Jaffe T, Straus D, Hovatta O, de la Chapelle A, Silber S, Page D. (1995) Diverse spermatogenic defects in humans caused by Y chromosome deletions encompassing a novel RNA-binding protein gene. Nature Genet. 10, 383-393.

8. Quereshi SJ, Ross AR, Ma K, Cooke HJ, Intyre MAM, Chandley AC, Hargreave TB. (1996) PCR screening for Y chromosome microdeletions: a first step towards the diagnosis of genetically determinined spermatogenic failure in men. Mol. Hum. Reprod. 2, 775-9.

9. Stuppia L, Mastroprimiano G, Calabrese G, Peila R, Tenaglia R, Palka G. (1996) Microdeletions in interval 6 of the Y chromosome detected by STS-PCR in 6 of 33 patients with idiopathic oligo- and azoospermia. Cytogenet. Cell. Genet. 72, 155-158.

10. Reijo R, Alagappan RK, Patrizio P, Page D. (1996) Severe oligospermia resulting from deletions of azoospermia factor gene on Y chromosome. Lancet. 347, 1290-1293.

11. Vogt PH, Edelmann A, Kirsch S, Henegariu O, Hirschmann P, Kiesewetter F, Kohn FM, Schill WB, Farah S, Ramos C, Hartmann M, Hartschuh W, Meschede D, Behre HM, Castel A, Nieschlag E, Weidner W, Grone H-J, Jung A, Engel W, Haidl G (1996) Human Y chromosome azoospermia factors (AZF) mapped to different subregions in Yq11. Hum. Mol. Genet. 5, 933-943.

12. Najmabadi H, Huang V, Yen P, Subbarao MN, Bhasin D, Banaag L, Naseeruddin S, de Kretser DM, Baker HWG, McLachlan RI, Loveland KA, Bhasin S. (1996) Substantial prevalence of microdeletions of the Y-chromosome in infertile men with idiopathic azoospermia and oligospermia detected using a sequence tagged site based mapping strategy. J. Clin. Endcrinol. Metabol. 81, 1347-1352 .

13. Nakahori Y, Kuroki Y, Komaki R, Kondoh N, Namiki M, Iwamoto T, Toda T, Kobayashi K. (1996) The Y chromosome region essential for spermatogenesis. Horm. Res. 46, (suppl.1) 20-23.

14. Pryor JL, Kent-First M, Muallem A, Van Bergen AH, Nolten WE, Meisner L, Roberts KP. (1997) Microdeletions in the Y chromosome of infertile men. New Eng. J. Med. $336,534-539$.

15. Foresta C, Ferlin A, Garolla A, Rossato M, Barbaux S, Bortoli A. (1997) Y-chromosome deletions in idiopathic severe testiculopathies. J. Clin. Endocrinol. Metabol. 82, 1075-1080.

16. Vereb M, Agulnik AI, Houston JT, Lipschultz LI, Lamb DJ and CE Bishop (1997) Absence of DAZ gene mutations in cases of non-obstructed azoospermia. Mol. Hum. Rep. 3, 55-59. 
17. Kremer JAM, Tuerlings JHAM, Meuleman, Schoute F, Mariman E, (1997) Microdeletions of the Y chromosome and intracytoplasmic sperm injection: from gene to clinic. Hum. Reprod. 12, 687-691.

18. Mulhall JP, Reijo R, Alagappan R, Brown L, Page D, Carson R. and Oates RD. (1997) Azoospermic men with deletion of the DAZ gene cluster are capable of completing spermatogenesis: fertilization, normal embryonic development and pregnancy occur when retrieved testicular spermatozoa are used for intracytoplasmic sperm injection. Hum. Rep. 12, 503-508.

19. Simoni M, Gromoll J, Dworniczak B, Rolf C, Abshagen K, Kamischke A, Carani C, Meschede D, Behre HN, Horst J, Nieschlag E. (1997) Screening for deletions of the $\mathrm{Y}$ chromosome involving the DAZ (Deleted in Azoospermia) gene in azoospermia and severe oligozoospermia. Fertil. Steril. 67, 542-7.

20. Van der Vent K, Montag M, Peshka B, Leygraaf J, Schwanitz G, Haidl G, Krebs D. and Van der Ven H (1997. Combined cytogenetic and $\mathrm{Y}$ chromosome microdeletion screening in males undergoing intracytoplasmic sperm injection. Mol. Hum. Reprod. 3, 699-704.

21. Girardi SK, Mielnik A, Schlegel PN. (1997. Submicroscopic deletions in the Y chromosome of infertile men. Hum. Reprod. 12, 1635-41.

22. Stuppia L, Gatta V, Mastroprimiano G, Pompetti F, Calabrese G, Guanciali Franchi P, Morizio E, Mingarelli R, Nicolai M, Tenaglia R, Improta L, Sforza V, Bisceglia S, Palka G (1997. Clustering of Y chromosome deletions in subinterval $E$ of interval 6 supports the existence of an oligozoospermia critical region outside the DAZ gene. $J$. Med. Genet. 34, 881-883.

23. Selva J, Kanafani S, Prigent $Y$, Poncet V and Bergère (1997) Incidence of AZF (Azoospermia Factor) deletions and familial forms of infertility among patients requiring Intracytoplasmic Spermatozoa Injection (ICSI)J. Ass. Rep. Genet. 14, 593-595.

24. Stuppia L, Gatta V, Calabrese G. Guanciali Franchi P, Morizio E, Bombieri C, Mingarelli R, Sforza V, Frajese G, Tenaglia R, Palka G. (1998) A quarter of men with idiopathic oligo-azoospermia display chromosomal abnormalities and microdeletions of different types in interval 6 of Yq11. Hum. Genet. 102, 566-570.

25. Foresta C, Ferlin A, Garolla A, Moro E, Pistorello M, Barbaux S, Rossato M. (1998). High frequency of welldefined Y-chromosome deletions in idiopathic Sertoli cellonly syndrome.Hum. Rep. 13, 302-307.

26. Barbaux S, Quintana-Murci L, Krausz C, Siffroi JP, Rouba H, Delafontaine D, Souleyreau-Therville N, Arvis G, Antoine JM, Taar JP, Tar A, Jeandidier E, Plessis G, Bourgeron T, Dadoune JP, Fellous M, McElreavey K (in press) A high frequency of $\mathrm{Y}$ chromosome deletions in non-idiopathic infertile males. J. Clin. End. Met.

27. Grimaldi P, Scarponi C, Rossi P, Rocchietti March M, Fabbri A, Isidori A, Spera G, Krausz C, Geremia R. (in press) Screening for $\mathrm{Y}$ chromosome deletions in azoospermic males. Mol. Hum. Rep.

28. Lahn BT and Page D. (1998) Functional coherence of the human Y chromosome. Science. 278, 675-680.
29. Tiepolo L. and Zuffardi O. (1976) Localization of factors controlling spermatogenesis in the nonfluorescent portion of the human $\mathrm{Y}$ chromosome long arm. Hum. Genet. 34, 119-124.

30. Vergnaud G, Page DC, Simmler MC, Brown L, Rouyer F, Noel B, Botstein D. de la Chapelle A. Weissenbach J (1986) A deletion map of the human Y chromosome based on DNA hybridization. Am. J. Hum. Genet. 38, 109-124.

31. Vollrath D, Foote S, Hilton A, Brown LG, BeerRomero P, Bogan JS, Page DC. (1992) The human Y chromosome: a 43-interval map based on naturally occuring deletions. Science. 258, 52-59.

32. Brown GM, Furlong RA, Sargent CA. (1998) Characterisation of the coding sequence and fine mapping of the human DFFRY gene and comparative Dffry gene. Hum. Mol. Gen. 7, 97-107

33. Linder P, Lasko PF, Ashburner M, Leroy P, Nielsen PJ, Nishi K, Schnier J, Slonimski PP. (1989) Birth of the D-EA-D box. Nature. 337, 121-2.

34) Greenfield A, Scott D, Pennisi D. (1996) An H-YDb epitope is encoded by a novel mouse $\mathrm{Y}$ chromosome gene. Nature Genetics. 14, 474-78.

35. Gondo H, Kudo J, White JW, Barr C, Selvanayagam P, Saunders GF. (1987) Differential expression of the human thymosin-beta 4 gene in lymphocytes, macrophages, and granulocytes. J. Immunol. 139, 3840-8.

36. Ma K, Inglis JD, Sharkey A, Bickmore WA, Hill RE, Prosser EJ, Speed RM, Thomson EJ. (1993) A Y chromosome gene family with RNA-binding protein homology: candidates for the azoospermia factor AZF controlling spermatogenesis. Cell. 75, 1287-1295 .

37. Prosser J, Inglis JD, Condie A, Ma K, Kerr S, Thakrar R, Taylor K, Cameron JM, Cooke HJ. (1996) Degeneracy in human multi-copy RBM (YRRM), a candidate spermatogenesis gene. Mammal. Genome. 7, 835-842.

38. Chai NN, Salido EC, Yen PH. (1997) Multiple functional copies of the RBM gene family, a spermatogenesis candidate on the human Y chromosome. Genomics. 45, 355-361.

39. Eliott DJ, Millar MR, Oghene K, Ross A, Kiesewetter F, Pryor J, McIntyre M, Hargreave TB, Saunders PTK, Vogt PH, Chandley AC, Cooke H. (1997). Expression of RBM in the nuclei of human germ cells is dependent on a critical region of the Y chromosome long arm. Proc. Natl. Acad. Sci. USA. 94, 3848-3853.

40. Chandley AC and Cooke HJ. (1994) Human male fertility-Y linked genes and spermatogenesis. Hum. Mol. Genet. 3, 1449-1452.

41. James TC, Elgin SC. (1986) Identification of a nonhistone chromosomal protein associated with heterochromatin in Drosophila melanogaster and its gene. Mol. Cell. Biol. 11, 3862-72.

42. Ho M, Chelly J, Carter N, Danek A, Crocker P, Monaco AP. (1994) Isolation of the gene for McLeod syndrome that encodes a novel membrane transport protein. Cell. 77, 869-80. 
43. Krausz C, McElreavey K, Weissenbach G, Forti G, Bishop C. (1998) Identification and mapping of a novel Y chromosome isoform of eIF-1A. Miniposter book, 10th European Workshop on Molecular and Cellular Endocrinology of the testis. Capri 28/03-01-04.

44. Dever TE. (1994) Determination of the amino acid sequence of rabbit, human, and wheat germ protein synthesis factor eIF-4C by cloning and chemical sequencing. J. Biol. Chem. 269, 3212-3218.

45. Saxena R, Brown LG, Hawkins T, Alagappan RK, Skaletsky H, Reeve MP, Reijo R, Rozen S, Dinulos MB, Disteche CM, Page DC. (1996) The DAZ gene cluster on the human Y chromosome arose from an autosomal gene that was transposed, repeatedly amplified and pruned. Nat. Gen. 14, 292-299.

46. Yen PH, Chai NN. and Salido EC. (1997) The human DAZ genes, a putative male infertility factor on the $Y$ chromosome, are highly polymorphic in the DAZ repeat regions. Mamm. Genome. 8, 756-759.

47. Eberhart CG, Maines JZ, Wasserman SA. (1996) Meiotic cell requirement for a fly homologue of human Deleted in Azoospermia. Nature. 381, 783-785.

48. Cook HJ, Lee M, Kerr S, Ruggiu M. (1996) A murine homologue of the human DAZ gene is autosomal and expressed only in male and female gonads. Hum. Mol. Gen. $5,513-516$

49. Ruggiu M, Speed R, Taggart M, McKay SJ, Kilanowski F, Saunders P, Dorin J, Cooke HJ. (1997). The mouse Dazla gene encodes a cytoplasmic protein essential for gametogenesis. Nature. 389, 73-77.

50. Agulnik A, Zharkikh A, Boettger-Tong H, Bourgeron T, McElreavey K, Bishop C (1998) Evolution of DAZ gene family suggests that Y-linked DAZ plays little, or limited, role in spermatogenesis but underlines a recent African origin for human populations. Hum. Mol. Gen. 7, 1371-1377.

51. Hendriks W, Schepens J, Bachner D, Rijss J, Zeeuwen P, Zechner U, Hameister H, Wieringa B. (1995) Molecular cloning of a mouse epithelial protein-tyrosin phosphatase with similarities to submembranous proteins. $J$ Cell Biochem. 59, 418-30.

52. Simoni M, Kamishke A, Nieschlag E. (1998) Current status of the molecular diagnosis of Y-chromosomal microdeletions in the work up of male fertility. Hum. Rep. $13,1764-1768$

53. Edwards, R.G. and Bishop, C.E. (1997) On the origin and frequency of $\mathrm{Y}$ chromosome deletions responsible for severe male infertility. Mol. Hum. Reprod. 3, 549-54.

54. Kent-First MG. S. Kol, Muallem A, Ofir R, Manor D, Blazer S, First N, Itskovitz-Eldor J. (1996) The incidence and possible relevance of Y-linked microdeletions in babies born after intracytoplasmic sperm injection and their infertile fathers. Mol. Hum. Rep. 2, 943-950.

55. Yen PH, Li XM, Tsai SP, Johnson C, Mohandas T, Shapiro LJ. (1990) Frequent deletions of the human X chromosome distal short arm result from recombination between low copy repetitive elements. Cell. 61, 603-610.
56. McClintock B. (1951) Chromosome organization and genic expression. Cold Spring Harbor Symposia on Quantitative Biology. XVI, 13-21.

57. Jobling MA, Williams G, Schiebel K, Pandya A, McElreavey K, Salas L, Rappold GA, Affara NA, TylerSmith C. (in press) A selective difference between human Y-chromosomal DNA haplotypes. Current Biology.

58. Palka G and Dallapiccola B. (1996) Widening of a Ychromosome interval- 6 deletion transmitted from a father to his infertile son accounts for an oligozoospermia critical region distal to the RBM1 and DAZ genes. Am. J. Hum. Genet. 59, 1393-1395

59. Brandell RA, Mielnik A, Liotta D. Ye Z, Veeck L, Palermo GD, Goldstein M, Schlegel PN. (1998) Effect of partial Y chromosome deletions on result of treatment for severe male factor infertility. Poster, 16th World Congress on Fert. and Steril. IFFS'98. San Francisco, USA.

60. Oates RD, Alagappan R, Reijo R. Brown L, Pooler L, Page D. (1998) The spectrum of spermatogenic deficiency in 20 men with $\mathrm{Y}$ interstitial microdeletions confined to the AZFc (DAZ) region. Poster, 16th World Congress on Fert. and Steril. IFFS'98. San Francisco, USA.

61. Rossato M, Ferlin A, Garolla A, Pistorello M, Foresta C. (1998) High fertilization rate in conventional in-vitro fertilization utilizing spermatozoa from an oligozoospermic subject presenting microdeletions of the $\mathrm{Y}$ chromosome long arm. Mol. Hum. Rep. 4, 473-476.

62. Hecht NB (1998) Molecular mechanism of male germ cell differentiation. BioEssays. 20, 555-561

Key words: Y chromosome, AZF, male infertility

Send correspondence to: Dr Csilla Krausz Immunogenetique Humaine, Institut Pasteur, 25, Rue du Docteur Roux, 75724 Paris, Cedex 15. France, Tel: 33145688920, Fax: 33140613153, E-mail: c.krausz@mednuc2.dfc.unifi.it; ckrausz@pasteur.fr

Received 10/18/98 Accepted 12/16/98 